\title{
American Studies News
}

The Nordic Association for American Studies Articles

(Approved on June 15, 1979)

Title

1. The name of the Association shall be the Nordic Association for American Studies.

\section{Aims}

2. The purpose of the Association shall be to encourage the study of the United States, particulary in Denmark, Finland, Iceland, Norway, and Sweden.

As means to this end the Association may concern itself with the holding of conferences, the publication of a periodical, and the investigation and encouragement of the means of travel for scholars from the five Nordic countries to and in the United States and within Scandinavia.

\section{Membership}

3. Membership of the Association shall be open to teachers, researchers, and other individuals concerned with American studies.

\section{Assembly}

4. The assembly shall consist of all dues-paying individuals who have been duly registered as members by the Executive Board.

\section{Executive}

5. The executive business of the Association shall be despatched by a board which shall be known as the Executive Board.

\section{Board}

6. The board shall consist of one member from each Nordic country, with one of the members being elected chairman by the General Meeting.

There shall also be from two to four deputy members from each Nordic country, without the right to vote except in the absence of a member from the country in question.

All members and deputy members shall be elected at each triennial General Meeting of the Association to hold office for a term of three years. If there is no General Meeting on the expiration of this term of office, the term shall continue automatically until a General Meeting is held. 
If a vacancy arises through the resignation or death of a member of the Board before the expiration of the term, the Executive Board shall have the right to fill the vacancy from among the deputy members.

The editor of the Association's periodical, if not a member of the Board, shall have the right to be present at board meetings but without a right to vote.

\section{Officers}

7. There shall be a chairman of the Association, a secretary, who shall keep records of proceedings, and a treasurer, who shall keep accounts.

The chairman shall be elected at the General Meetings of the Association to serve until the next General Meeting but always at least three years.

The secretary and the treasurer shall be elected by the Executive Board for a term of three years.

A board member shall have the right to serve as an officer.

The Board shall elect a vice-chairman from its own number.

On completion of their term of office, the chairman and the board members shall, at the General Meeting, vacate their places and may offer themselves for re-election.

\section{General Meetings}

8. General Meetings of the Association shall be held every three years at such time as the Board shall determine.

An extraordinary General Meeting may be convened at not less than six weeks' notice at the request of the majority of the full Board.

All registered members of the Association shall have the right to vote at such meetings.

The chairman of the Board, or in his/her absence, the vice-chairman of the Board, shall preside at all sessions of the General Meeting.

Any matter before the Meeting shall be adopted by a simple majority of the votes given thereon.

In case of a tie, the chairman shall have the casting vote.

\section{National Subcommittees}

9. The executive Board shall have the right to delegate authority in matters pertaining to a particular member country to national subcommittees which shall be composed of the Board member and the deputy board members from the country in question.

The national subcommittees shall have the right to arrange conferences and concern themselves with other activities within limits set by the Executive Board.

The national subcommittees shall keep the Executive Board informed of all of their activities.

\section{Amendment}

10. These articles may be amended by majority vote of the General Meeting, due notice of the proposed amendment having been given to all members in advance. 
CHAIRMAN

Tuomo Laitinen

Kanavamaki 13 E 23

SF-00840 HELSINKI 84

Finland

VICE-CHAIRMAN

Henrik Rosenmeier

Amalievej 16

1875-KBBENHAVN V

Denmark

MEMBERS

Fredrik Chr. Bregger

Rypeveien 75

9014-HAPET

Norway

Olov Fryckstedt

Tuvangsvagen $3 \mathrm{~A}$

75245 UPPSALA

Sweden

SECRETARY

Markku Henriksson

Susitie 3 as 4

SF-00800 HELSINKI 80

Finland

\section{DEPUTY MEMBERS}

Denmark:

Ole B. Bom

5 Benvedvaenget

DK-2830 VIRUM, Denmark

Finland:

Jerker A. Eriksson

Engelinaukio 2 A 5

SF-00150 HELSINKI 15

Markku Henriksson

Susitie 3 as 4

SF-00800 HELSINKI 80

Norway:

Ingeborg Aasnes

Tvetenveien 231

OSLO 6

Sweden:

Rolf Lundén

Stigbergsvag. $2 \mathrm{~B}$

75242 UPPSALA
University of Tampere

P.O.B. 607

SF-33101 TAMPERE 10, Finland

Kebenhavns Universitet

Njålsgade 84

23 KøBENHAVN S, Danmark

Universitetet i Tromse

Postboks 1090

9001 TROMSB, Norway

Uppsala Universitet

Box 513

75120 UPPSALA, Sweden

Historian tutkimus ja dokumentaatiolaitos, The University of Helsinki, Meritullinkatu 14 A 4 SF-00170 HELSINKI 17,

Finland

Bengt Jiirgensen

Copenhagen School of Economics and Business Administration

Fabrikvej 7,

DK-2000 COPENHAGEN F

Reino Erma

University of Tampere

PL 607

33101 TAMPERE 10

Marja Wuorenheimo

Vaskiniementie 3 B

SF-00200 HELSINKI 20

Robert Baehr

Solberggt. 4

N-4890 GRIMSTAD

Göran Rystad

Spolegatan 12 A

S-222 20 LUND 